European Journal of STEM Education, 1:3 (2016), 45

ISSN: $2468-4368$

\title{
Learners' performance in Mathematics: A case study of public high schools, South Africa
}

Lawrence Mapaire*

Geluksdal Sekondere Skool, SOUTH AFRICA

*Corresponding Author: lawrencemapaire@yahoo.com

Citation: Mapaire, L. (2016) Learners' performance in Mathematics: A case study of public high schools, South Africa, European Journal of STEM Education, 1:3 (2016), 45.

doi: http://dx.doi.org/10.20897/lectito.201645

Received: June 30, 2016; Accepted: August 18, 2016; Published: November 4, 2016

\begin{abstract}
Mathematics is fundamental to national prosperity in providing tools for understanding science, technology, engineering and economics. It is essential in public decision-making and for participation in the knowledge economy. Mathematics equips pupils with uniquely powerful ways to describe, analyse and change the world. It can stimulate moments of pleasure and wonder for all pupils when they solve a problem for the first time, discover a more elegant solution, or notice hidden connections. This study investigated a societal problem the ongoing poor performance in mathematics. The study described what is going on by means of statistical methods and reported in statistical language and hence, descriptive quantitative research paradigm infused with content analysis (cartoons) was adopted. The sample for the study comprised of a total of ten underperforming (failing) secondary schools obtained by simple random sampling; 50 Grade 12 mathematics educators and 200 Grade 12 mathematics learners were derived through stratified sampling technique.
\end{abstract}

Keywords: mathematics, performance, pass rate, underperforming secondary school

\section{INTRODUCTION}

Mathematics is widely acknowledged as one of the cornerstones of future development and prosperity. Professor Kader Asmal (2003) classifies mathematics as the priority of all priorities; Ibn Khaldun, Muqaddima (1332) as Gouba (2008: slide 2) quotes, stresses that, "Education should be started with mathematics, for it forms well designed brains that are able to reason right"; mathematics is generally accepted as a gateway subject "enabling discipline" (Pandor, 2006a:2); President Thabo Mbeki (2000; 2001), emphasised the centrality of mathematics as part of our human development strategy; as for Justina (1991), mathematics is increasingly recognised as one of the most reliable indicators for measuring socio-economic and geo-political development among nations; and finally, Azikiwe puts it, "Mathematics is the bedrock of science while science is the necessity for technological and industrial development" (Betiku, 1999:49). In sharp contrast to these perceptions, the low mathematics pass rates at Grade 12 level are not only a source of frustrations and embarrassment for the learners concerned, but also reflect a low-level return for substantial investment made by the Government, communities, and parents in the education of their children.

The education system takes a lion's share of resources, placing South Africa at or near the top of the international league in terms of proportion of national resources (GDP) devoted to the education spending. Since the transition to democracy, resources devoted to school education have increased considerably and large resource shifts have taken place to the poorer schools (Van der Berg, 2001), yet outputs of successful matriculants or of those matriculating with university exemption are stagnating or declining (Van der Berg and Burger, 2002). Accordingly, the Minister of Finance, Mr Trevor Manuel (Budget 2008) posits that "Education is 
our central objective of broadening opportunity and fighting poverty. This budget priorities school building, early childhood education, school books and educator remuneration. The education spending accounts for R105.7 billion." Furthermore, Mr Trevor Manuel (Budget 2009) encapsulates that, "Government's contribution to public education remains our single largest investment, because we know that it is the key to reducing poverty and accelerating long-term economic growth." On the same note, Mr Pravin Gordhan (current Minister of Finance) reiterates that, "Education spending remains our largest item of spending; giving meaning to our commitment that it is our number one priority. The total budget for education ... is R165.1 billion."(Budget 2010) Consequently, with about 5.3 percent of gross domestic product and 20 percent of total state expenditure on education, South Africa has one of the highest rates of public investment in education in the world (Budget 2008; 2009; 2010).

In addition, a number of programmes and initiatives have been put in place: the South African National Department of Education in 2000, introduced a National Strategy for Mathematics, Science and Technology Education (now called DINALEDI project); the North West Department of Education established Mathematics, Science and Technology Unit (MSTU); the Western Cape Education Department, launched the Khanya Project. The President, Jacob Zuma (2009) reiterates the non-negotiables, "Teachers should be in school, in class, on time, teaching, with no neglect of duty and abuse of pupils! The children should be in class, on time, learning, be respectful of their teachers and each other, and do their homework." On the other hand, the Minister of Basic Education, Mrs Angelina Matsie Motshekga, MP, in 2010, launched the Action Plan to 2014: Towards the Realisation of Schooling 2025, in order to avoid ad hoc and fragmented interventions. (Report on the National Senior Certificate Examination Results: 2010).

Furthermore commitment in education are witnessed in a number of initiatives and programmes such as HIV/AIDS awareness programmes in schools, reducing average class sizes in schools serving lower income communities, adult basic education and training (ABET), increasing school expenditure on school buildings, recapitalising technical high schools, strengthening teacher training programmes, the Fee-free Schools, National Schools Nutrition Programme, Scholar Transport, Saturday classes, winter school, Senior Secondary Intervention Programme (SSIP), Study Mates, Teach South Africa, University bridging courses, learner ships and e-learning channels.

Despite the fact that South Africa spends a large budgetary commitment (about $20 \%$ of its annual budget on education), programmes and initiatives, the entire schooling system is characterised with series of low matriculation pass rates especially in gateway subjects (mathematics, science and accounting) (Naidoo, 2004; Coetzee, 2008). The quality of education remains very poor, and the output rate has not improved. The Star (January 8 2010) stresses that the standard of public education is not reflecting a corresponding correlation with the massive investment. The NSC examination of 2008 was the first based on the New Curriculum Statement (Curriculum 2005). The following table (Table1) gives an insight into the national pass rates of all the learning areas (mathematics statistics interpolated as it was the area of study).

Table 1. National Senior Certificate Pass Rates In All Learning Areas (Mathematics statistics Interpolated): 2008 to 2010 Educational Measurement, Assessment and Public Examinations (2010)

\begin{tabular}{clccc}
\hline Year & & Total Wrote & Total Passed & \% Passed \\
\hline $\mathbf{2 0 0 8}$ & All subjects & 554664 & 345001 & 62.6 \\
\hline & Maths & $\mathbf{2 9 8 ~ 8 2 1}$ & $\mathbf{1 3 6 5 0 3}$ & $\mathbf{4 5 . 6}$ \\
\hline $\mathbf{2 0 0 9}$ & All subjects & 580527 & 351829 & 60.6 \\
\hline & Maths & $\mathbf{2 9 0 4 0 7}$ & $\mathbf{1 3 3 5 0 5}$ & $\mathbf{4 6}$ \\
\hline $\mathbf{2 0 1 0}$ & All subjects & 537543 & 364513 & 67.8 \\
\hline & Maths & $\mathbf{2 6 3 0 3 4}$ & $\mathbf{1 2 4} \mathbf{7 4 9}$ & $\mathbf{4 7 . 4}$ \\
\hline
\end{tabular}

Table 1 above depicts, the first NSC examination achieving a national pass rate of 62.6 percent and national mathematics pass rate of 45.6 percent. Commenting on the Matric Results of 2008, Pandor (2009) best describes matric pass rates as "pathetic" (educationweb.co.za). In 2009, the national pass rate plummeted to 60.6 percent while the national mathematics pass rate increased by 0.4 percent to 46.0 percent. Govender (2010) points out that, "The 60.6 percent pass rate recorded for 2009 is a far cry from the 70.7 percent achieved in 2004. The national matric pass rate of 60.6 percent which has been declining since 2004 is a national disgrace." Motshekga MP, Minister of Basic Education (2010) on announcing South Africa's 2009 National Senior Certificate Results, regrettably admits "This achievement is depressing", and adds that, "matric results are economic failure."

2010 witnessed a national pass rate of 67.8 percent, a massive improvement of 7.2 percent from 2009. More meaningfully, Zapiro's (2010) Cartoon A depicts a proud, Angie Motshekga, Minister of Basic Education, 
announcing that $67.8 \%$ of students passed the 2010 exams - a nearly 7 percent plus increase from the previous year and a "remarkable achievement!" she says.

Figure 1. Cartoon A: Showing "THE AMAZING ANGIE: MATRIC PASS RATES”

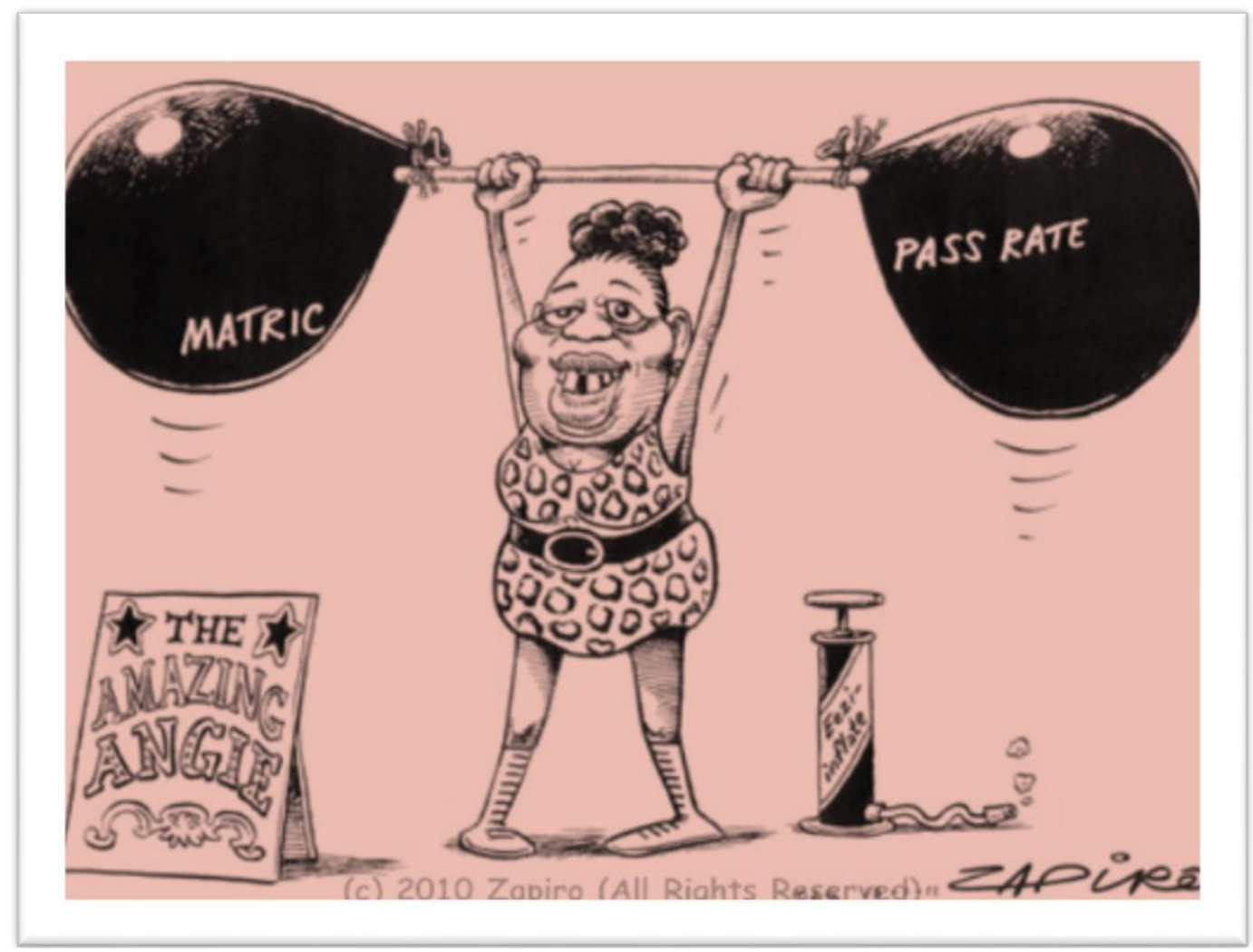

Shapiro, 2011.Published in Mail \& Guardian on 13 Jan

Contrarily to "The amazing Angie: Matric pass rates" an open mind questions, "Was the matric pass rate of 2011 a true reflection of learner achievement?" The obvious answer as according to Cartoon A becomes NO! The balloons and the pump suggest 2011 matric pass rate was inflated. On the same token (Table1), according to Pandor (2011), "The number of learners sitting for Grade 12 mathematics declined from 298821 in 2008 to 290407 in 2009 and 263034 in 2010."

Conclusively, Dr Valley (Wits Policy Units, 2008) criticises the 30\% and 40\% benchmarks for passes feeling these were too low. He points out that, "We are setting our sights too low. There is nothing to celebrate. Our schooling system is failing our young people and we need to revive it." (http//www.educationweb.co.za)

\section{METHODOLOGY}

This study followed descriptive quantitative survey research and content analysis methodologies. Descriptive quantitative survey research was seen ideal, because it is concerned with the present, although it often considers past events and influences as they relate to current conditions (Cohen and Manion 1994:67); concerned with the relationship of one set of facts to another (Bell 2005:13); mathematical procedures are followed to aggregate and summarise the evidence (Romberg, 1992: 52); a systematic process in which numerical data are utilised to obtain information about the world (Patton, 1990:20). As for Dooley (1990) and Neill (2004), standardised measurement procedures are used to assign numbers to observations, and statistical procedures are used to analyse quantitative data (Durrheim 1999b:96). Furthermore, content analysis or textual analysis was adopted as it uses a sample of images rather than people (Haralambos, Holborn and Heald, 1995:854-855), a technique for making inferences by objectively and systematically identifying specified characteristics of antecedents of communication (Holti, 1969), and texts are studied as to authorship, authenticity or meaning (Neuendorf, 2002). In addition, the results of content analysis allow researchers to identify, as well as quantify, specific ideas, concepts, and their associated patterns, and trends of ideas that occur within a specific group or over time (Krippendorff, 1980 and Weber, 1990). More importantly, the results of content analysis are numbers and percentages and further uncover causes and promote awareness. 


\section{PARTICIPANTS}

In this study, the population was 138 Grade 12 mathematics teachers and 1153 Grade 12 mathematics learners at 23 underperforming (failing) secondary schools in Gauteng East district. The sampling of participants of this study began with simple random sampling of 10 underperforming secondary schools. Stratified random sampling was applied to obtain two hundred learners (136 boys and 64 girls) and fifty teachers (17 females and 33 males). The sample responded to a respondent-centred questionnaire with closed and open questions or statements (Burton and Bartlett, 2009:175; Struwig and Stead, 2004:92; De Vos, 1998:89 and Terre Blanche et al, 2006:486). As for content analysis, the corpus (the body of information) was daily and weekly newspapers. The sample of the study was images on the cartoon page - educational cartoons (Weber, 1990; and McNamara, 1998).

\section{QUANTITATIVE DATA ANALYSIS}

According to Neuman (1997:294), a researcher provides tables, graphs and charts to give the reader a condensed picture of the data. The data was coded before computing it. Coding data, according to Neuman (1997:295), means "systematically reorganising data that is computer readable." The respondents' responses were assessed on the basis of their agreement or disagreement with the attitudinal declarative statements, such as; yes or no and Likert's four-point scale, that is; Strongly Agree (SA); Agree (A); Disagree (D); Strongly Disagree (SD) - which forces a decision, were used in the study.

Statistical Programme for Social Sciences (SPSS), one of the most widely used programs for statistical analysis (a) in social sciences and (b) data management (Nie, Bent and Hull; 1970) was used to analyse responses of the learner and the educator questionnaires. The descriptive statistical analysis used in this study consisted of the number of respondents, lists, frequency distribution tables, percentage tables, cross tabulation and statistical graphs of item variables.

\section{FINDINGS}

As the purpose of the present investigation was to explore factors that cause low pass rates in mathematics at Grade 12 level in public high schools; all participants were (mathematics) learners and educators. Five factors (Educational policies - Learning areas; Promotion policy and Educator's and Learners' behaviour - School or classroom discipline; Drugs and alcohol abuse; and Learner pregnancy) resulting from questionnaires' responses and analysis are presented here.

Findings with regard to the first problem question and the aim of this study: To what extent will educational policies contribute to Grade 12 learners' mathematics pass rates?

Table 2. Educational policies

\begin{tabular}{lllll}
\hline The number of learning areas is too many & A & D & $\mathbf{\%}$ & $\mathbf{\%}$ \\
\hline Condoned mathematics learners & 216 & 31 & 88 & 12 \\
\hline
\end{tabular}

\section{LEARNING AREAS}

To confirm responses from the questionnaires administered about some educational policies in place, Table 2 revealed that the low pass rates in mathematics at Grade 12 level were largely due to the existing educational policies (learning areas condoned learners). To recap the overall responses, out of 250 respondents, 216 respondents $(88 \%)$ indicated that low pass rates in mathematics at Grade 12 level were greatly due to the number of learning areas prescribed by NCS (a learner must do at least seven subjects at FET). On the other hand, 31 participants (12\%) disagreed of which, 21 participants (08\%) disagreed and 10 participants (04\%) strongly disagreed.

This suggests that the majority of participants, as reflected on the table suggest that mathematics Grade 12 learners were performing poorly due to the number of learning areas. One of the purposes of higher education as stipulated in the White Paper (DoE, 1997:7) is "to contribute to the socialisation of enlightened, responsible and constructively critical citizens" this may suggest subject specialisation - strong discipline (content) base. Accordingly, Muller (2009) sees curriculum in terms of the differences in discipline as well as coherence. He concurs with Biglan's (1973:204) division of academic areas into (a) a single paradigm (making it hard or soft), (b) practical application (in terms of pure or applied), and, finally, whether it falls under life systems or not. In accordance with the thinking, curriculum designers may bring to fore, the introduction of subject specialisation 
as from Grade 10 and perhaps, a minimum of three learning areas would enhance good pass rates not in mathematics only, but even in other gateway subjects.

\section{PROMOTION POLICIES}

In regards to Promotion Policy (Table 2 above), an overwhelmingly 174 respondents (69\%) agreed or strongly agreed with the assertion that "Condoned learners" contribute to low pass rates in mathematics at Grade 12 level in public high schools in Gauteng East District. The 69\% was made up of, fifty-eight respondents $(23 \%)$ who strongly agreed and a further one hundred and sixteen respondents $(46 \%)$ who agreed. Contrarily, 76 respondents (31\%) disagreed; 46 respondents $(18 \%)$ disagreed and 21 respondents (13\%) strongly disagreed.

Indiscriminate promotion from lower classes in schools significantly leads to poor matric pass rates particularly in mathematics. Condonation, according to National Protocol for Assessment Grades 1-12, is the relaxation of promotion requirements as contemplated in paragraph 29(1) (b) of the policy document, pertaining to the programme and promotion requirements of the National Curriculum statement. Condoning (assisting learners to reach matric) to a greater extent, contributes to low matric pass rates in mathematics (as mostly learners are condoned in mathematics from Grade 1 up to Grade 12 level).

On the other hand, keeping learners in a grade where they are not doing well is an indication that the education system is not good. A recent survey suggests that 10 percent of the learners across all grades are 3 or more years outside the age-group norm. The Department of Basic Education's age-group norms state that a child should be seven years in grade 1, eight in grade 2 and so on. Grade repetition has resulted in a large number of over-age learners in our education system instead of high pass rates Meny-Gilbert (the teacher 2010).

According to Ncana (The Times 2010), schools are marked with a significant age differential or age mixing between learners and older adolescents. Meny-Gilbert (2010) talks about multi-age classrooms, and consequently, many teachers struggle to cope with reality. The curriculum for each grade is aimed at a particular pedagogic development stage-premised on children being of a certain age.

Consequently, grade repetition (learners repeating failed grade at most three times) contributes to a significantly large number of over-age learners with spill over effects of many learner pregnancies. These findings confirmed to a certain extent to the findings of Vogel (2003:115) who synthesises it all, "the current system of giving a child a condoned pass is a double-edged sword."

Findings regarding the second problem question and the aim of this study: How will the behaviour of educators' and learners' affect the overall Grade 12 mathematics pass rates?

Table 3: Behaviour of educators' and learners'

\begin{tabular}{lllll}
\hline & A & $\mathbf{D}$ & $\mathbf{\%}$ & $\mathbf{\%}$ \\
\hline Indiscipline amongst educators' and learners' & 153 & 97 & 61 & 39 \\
\hline
\end{tabular}

\section{SCHOOL (CLASSROOM) DISCIPLINE}

As evident in Table 3, 60 participants (24\%) strongly agreed that 'Indiscipline amongst educators' and learners" was a contributing factor to low pass rates in mathematics at Grade 12 level in public high schools in Gauteng East District. In addition, 93 participants (37\%) agreed, hence $61 \%$ of the respondents were in agreement with the assertion. On the other hand, 97 participants $(39 \%)$ disagreed, of which, 59 participants (24\%) disagreed and 38 participants (15\%) strongly disagreed. South African society has undergone major social, economic and political changes over the past few years as we have sought to establish a democratic and humane nation. Among the changes in the education sector has been the banning of corporal punishment in all schools under the Convention on the Rights of the Child (CRC) by being a signatory and the African Charter on the Rights and Welfare of the Child (ACRWC) which compels that a child who is subjected to school or parental discipline shall be treated with humanity and with respect for the inherent dignity of the child.

This table (Table 3 above) put it in clear terms how the respondents felt about school discipline. This may suggest that participants had the following in mind when they were completing the questionnaire:

- Section 12 of the South African Constitution states that: Everyone has the right not to be treated or punished in a cruel, inhuman or degrading way.

- The National Education Policy Act (1996) says, No person shall administer corporal punishment or subject a student to psychological or physical abuse at any educational institution. 
- The South African Schools Act (1996) says: (1) No person may administer corporal punishment at a school to a learner; (2) Any person who contravenes subsection 1 is guilty of an offense, and liable on conviction to a sentence which could be imposed for assault.

Findings from the present study were thus, further consistent with Siwela's cartoon. Siwela (Feb 17 2012: The Citizen) rightly captures morning order at a school with the following cartoon. The "teacher", a role model to be, is always... late and subsequently, learners are also coming late to school.

Figure 2. Cartoon B: "School: Always... late! Like you' Sir"

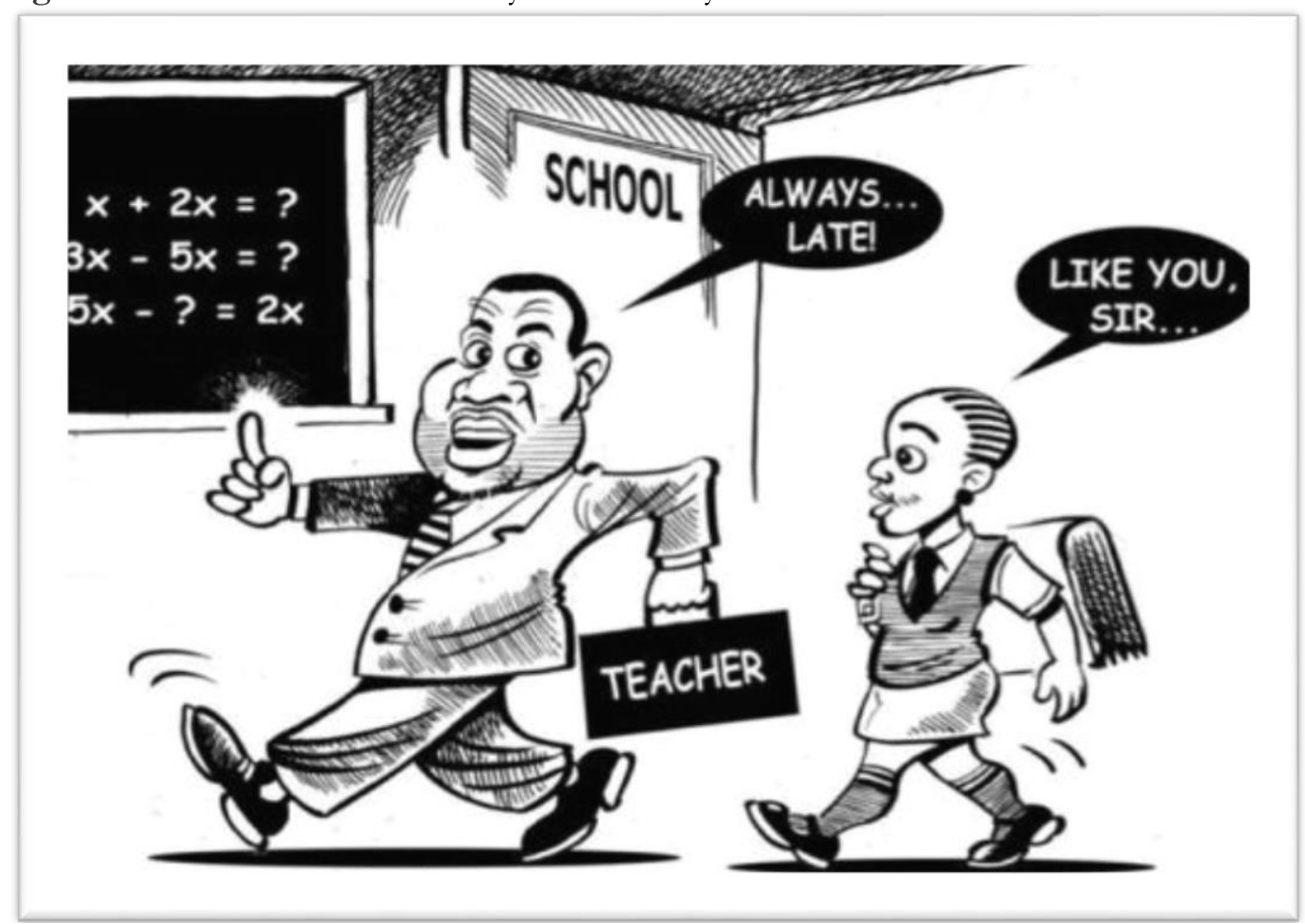

Siwela: Feb 17 2012: The Citizen

It is worth noting here that lack of discipline in many schools stems from the 1970's where pupils were given the power by revolutionary forces to make the country ungovernable. Pupils to this day, still think they can run the school. In the 1980's there was a policy "Pass one, pass all" and in those circumstances, it was almost impossible to maintain standards. Historically, this crisis has been intensified by the widespread political unrests which in turn eroded discipline in schools. This political unrest was expressed by parents, learners, political organisations and educators struggle against the previous Bantu education under apartheid. De Villiers (1997:76) emphasises this statement when he states that the political factors, especially the role the school played in apartheid played a major role in undermining discipline in the South African Black schools.

The findings of this study, to a very great extent, in South African schools suggests that lack of discipline and self-discipline among educators and high school pupils has probably led to a continuation of unsuccessful learning and teaching and furthermore, perpetuation of low pass rates in mathematics.

Table 4. Behaviour of educators' and learners' drug and alcohol abuse

\begin{tabular}{lllll}
\hline & $\mathrm{A}$ & $\mathrm{D}$ & $\%$ & $\%$ \\
\hline Drugs and alcohol abuse & 154 & 96 & 62 & 38 \\
\hline
\end{tabular}

As evident in Table 4, negative behaviour (drugs and alcohol abuse) of educators' and learners' towards teaching and learning was statistically significant in contributing to low pass rates in mathematics at Grade 12 level. The results showed more than half of the respondents ( $62 \%$ of the respondents) agreed that negative behaviour of both educators and learners was one of the main factors causing low pass rates in mathematics. Less than half of the respondents (38\%) disagreed with the assertion.

The findings are in line with the results of the most informative study concerning the prevalence of drinking behaviour of youth and adolescents. The results of the study (Rocha-Silva, de Miranda and Erasmus, 1996) 
revealed that $42.5 \%$ of the respondents reported having used alcohol at some stage during their lives. From a study of a sample of 7340 students in Grades 8 to 12 from 16 high schools (Flisher et al, 1993a, b), of the total sample, $53.2 \%$ of the respondents reported ever using alcohol. According to a report from the Bureau of Justice (2011), $85 \%$ of the teenagers claim that they know where to obtain marijuana, while $29 \%$ state that someone has offered or sold them an illegal substance at school.

Nationally, Yalo (2011), pictorially identifies (in the Sowetan newspaper) negative influences on education of many school goers of these days. Learners' drinking attract much attention in the press and hence, Yalo rightly shows the Class of 2011 concentrating on drugs, gambling, smoking, glue sniffing and violence instead of doing homework and school based assessments. The following cartoon (Cartoon C) depicts the education of today.

Figure 3. Cartoon C: Education today

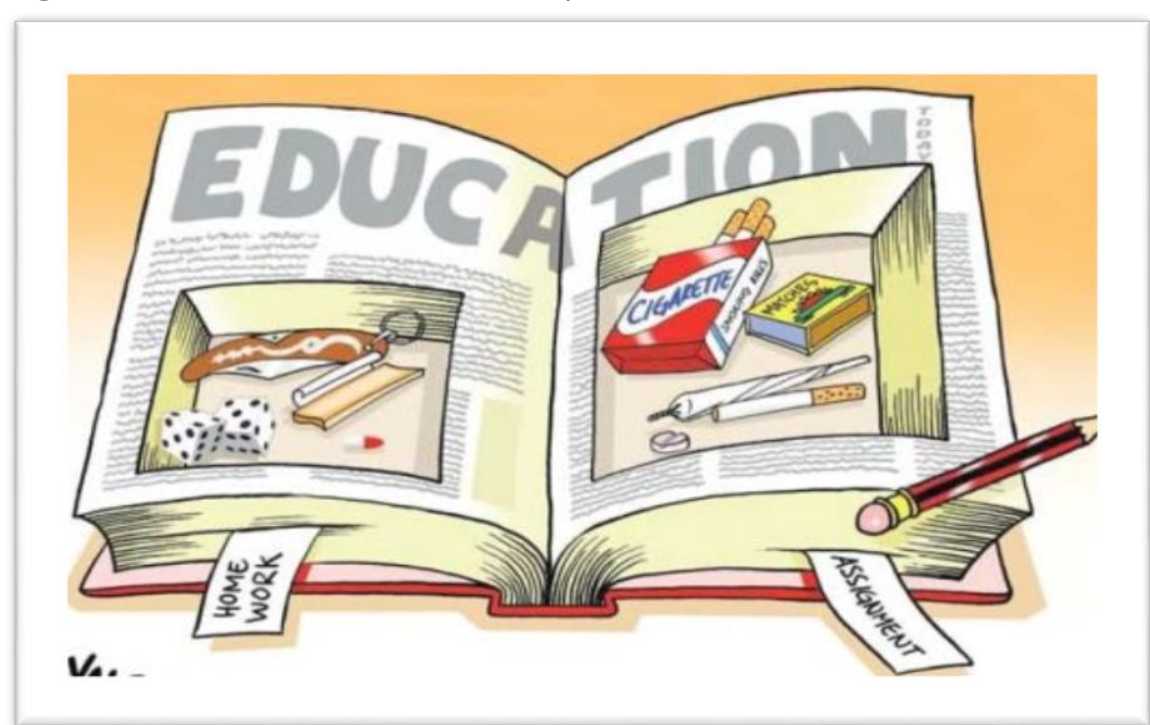

Yalo | Mar 25, 2011 | Sowetan

Lastly, the findings are in line with the United Nations World Drug Report (2009). The recent United Nations World Drug Report has named South Africa as one of the worlds' drug capitals. Experts have expressed concern that drug abuse is epidemic in South African' schools were the drug level of drug users has dropped from teens to between 9 to 10 (Mohlala, theTeacher 2010). In addition, the consumption of alcoholic beverages has a very long history in South Africa dating back to very ancient times (Gumede, 1995).

Figure 3. Learner Pregnancy

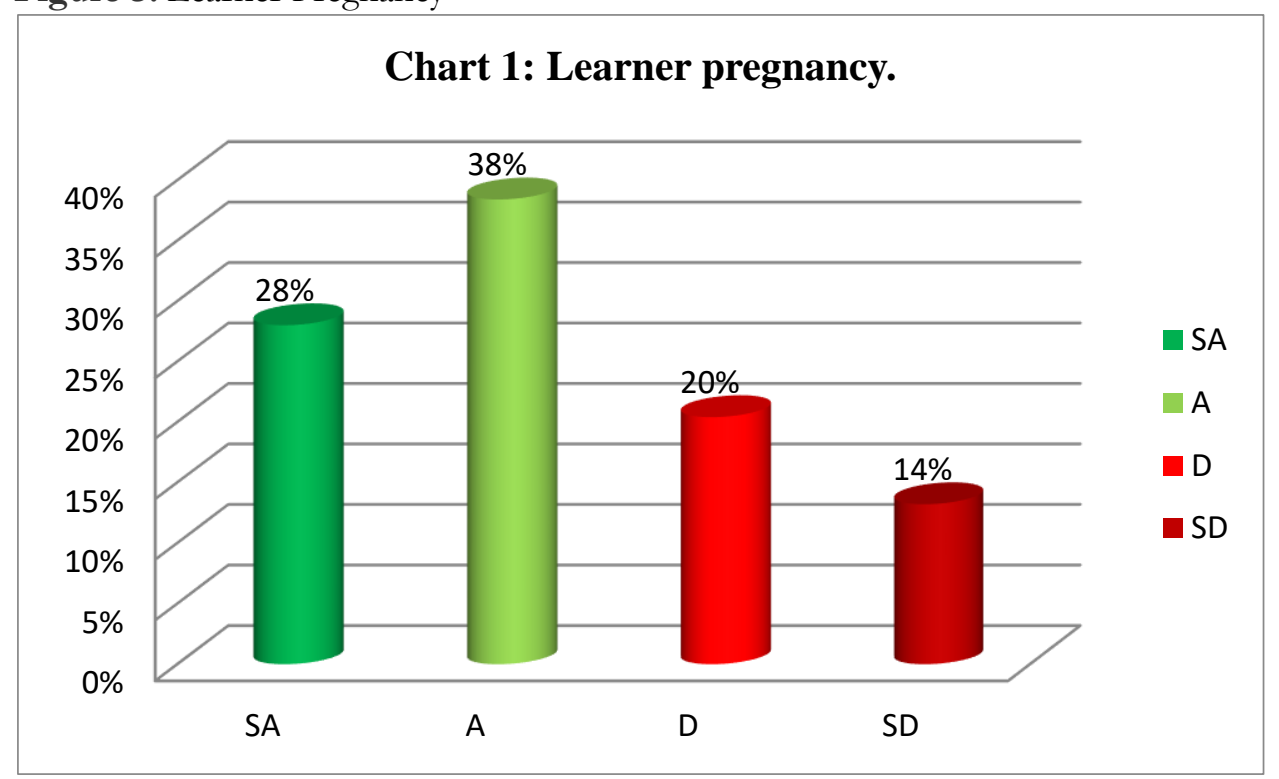


As with the results in Chart 1, seventy respondents (28\%) strongly agreed that "Learner pregnancy" was a contributory factor to low pass rates in mathematics at Grade 12 level in public high schools in Gauteng East District. In addition, ninety-six respondents (38\%) agreed to the assertion. On the other hand, eighty-four respondents (33\%) disagreed of which, fifty-one respondents $(20 \%)$ disagreed and thirty three respondents $(14 \%)$ strongly disagreed. Teenage pregnancy has emerged as one of the many challenges facing schools. The high agreement to the assertion could have been informed by the following consequences:

- Health (high risk of infant mortality);

- Educational (difficult to learn during pregnancy, absenteeism);

- Economic (exacerbate poverty)

- Social (stigma and discrimination, de-motivated parents, distracting other learners [being envied]).

Petje (2000), in the introductory remarks of Circular 53/2000 highlights teenage pregnancy statistics in South Africa, for instance, 100000 legal abortions have been carried out since the passing of the choice on Termination of Pregnancy Act 92 of 1996.

Nationally, a similar pattern holds, as Yalo's cartoon shows. Yalo (Feb 22, 2011), reacts to the release of statistics depicting a frightening high instance of schoolgirl pregnancies with the following cartoon in one of the national newspaper - Sowetan.

Figure 4. Cartoon D: School pregnancies (Yalo Feb 22, 2011 Sowetan)

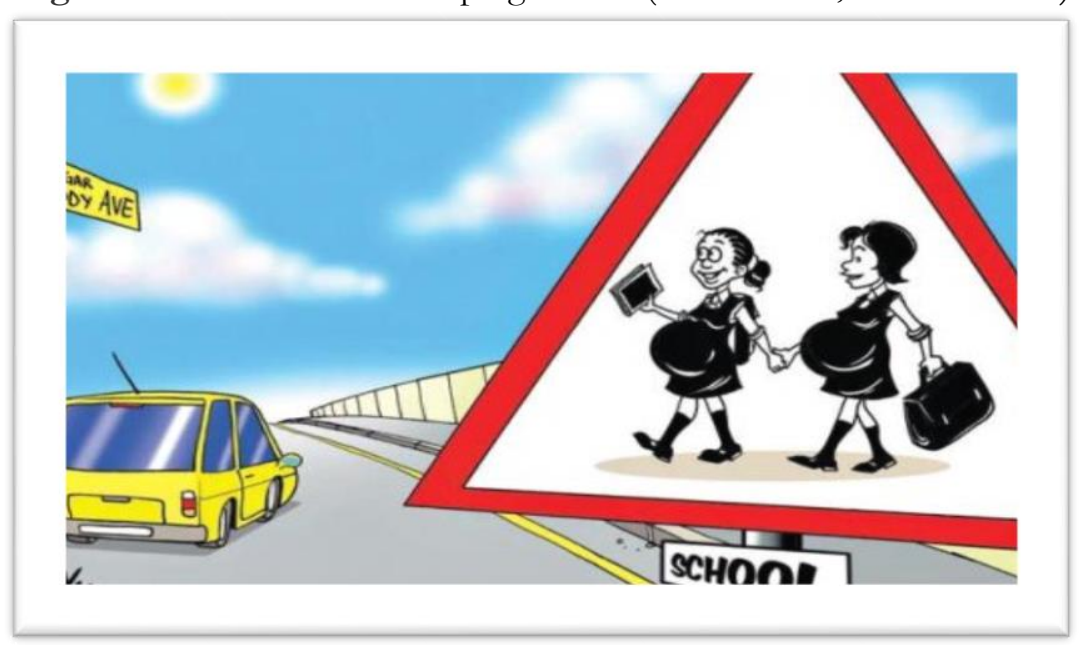

The findings are further supported by statuary instruments. According to the South African Constitution, 1996 (Act 108 of 1996) and South African Schools Act, Act number 84 of 1996, a pregnant learner may absent herself from school and be allowed to continue with her school after the delivery of her baby. In terms of this Act (SASA), a pregnant learner may not be expelled from school on the basis of her pregnancy, nor may she be refused admission to school on the basis that she is or was pregnant. Motshekga Angie (Minister of Basic Education) in Ncana (The Times Thursday May 20 2010) concurs with the findings by pointing out that, 'Pregnancies in schools are still through the roof.'

In a rights-based society, young girls who fall pregnant should not be denied access to education and this is entrenched in law in South Africa through the Constitution and Schools Act of 1996. In 2007, the Department of Education released Measures for the Prevention and Management of Learner Pregnancy. Not without controversy, the guidelines continue to advocate for the right of pregnant girls to remain in school, but suggests up to a two year waiting period before girls can return to school in the interest of the rights of the child. Any proposed shift in policy and practice needs to be informed by a well-rounded understanding of the context of teenage pregnancy.

The incidence of teen pregnancy is growing, according to the Human Science Research Council (HSRC), a government think tank. Out of every 1000 girls in school in 2004, 51 were pregnant. The number jumped to 62 in 2008, the most recent data available. Teenage pregnancy has militated against the educational success of girls in South Africa. Statistics show that 4 out of 10 girls become pregnant overall at least once before 20.

However, while it is acknowledged that the population of pregnant and former pregnant learners in public high schools is on the increase due to these positive policy measures (Pandor, 2007), the capacity of schools to cope with this current challenge needs to be established. 


\section{RECOMMENDATIONS}

Based on the findings reached in the study, the following recommendations were made.

- No teacher education policy framework: Implement train the educator programme (Human resource development training programmes);

- Approaches to managing absenteeism should be devised in a holistic way, to take account of the broader problems that contribute to absenteeism;

- Department to pronounce clear guidelines about classroom management and discipline strategies;

- A national policy on teenage pregnancy with clear guidelines that safeguard rights to education should be crafted.

- To strengthen the subject specialisation knowledge of the learners at FET, narrowing subjects to at least three as from Grade 10.

\section{CONCLUSION}

The research led to the following conclusions:

The Outcomes-based Education has taught learners that they can pass with minimum mathematics knowledge. OBE develops short memory but does nothing to develop long term knowledge and skills. For learners to competitively participate in the technologically advancing global village, subject specialisation is a prerequisite. According to the findings of present study, learners perform significantly poorly largely due to too many learning areas on offer; indiscipline (both educators and learners); promotion policies; drug and alcohol abuse and learner pregnancy.

\section{REFERENCES}

Asmal, K. (2003). Transforming Learning and Teaching through ICT. Department of Education. Draft White paper on e-Education.

Betiku, O. F. (1999). Resources for the effective implementation of the 2- and 3- dimensional mathematics topics at the Junior and Senior secondary school levels in the Federal Capital Territory, Abuja. Nigerian Journal of Curriculum Studies, 6 (2): 49-52.

Biglan, A. (1973). Relarionship between subject matter characteristics and the structure and output of university department. Journal of Applied Pscyhology, 57 (3): 204 - 213.

Burton, D. and Bartlett, S. (2009). Key Issues For Education Researches. Los Angeles: Sage.

Coetzee, J. (2008). Supplementary Tuition in Mathematics: Exploring the Industry in Eastern Cape.

Cohen, L. and Manion, L. (1994). Research Methods In Education. $4^{\text {th }}$ edition. London: Routledge.

Denzin, N.K. and Lincoln, Y. S. (1994). Handbook OfQualitative Research. Thousand Oaks: Siege.

Department of Education. (1997). Education White Paper 3: A programme for the transformation of higher education. Pretoria: Government Printers.

De vos, A. S. (1998). Research At Grass Roots: A Primer For The Caring Professions. Pretoria: Van Schaik.

Dooley, D. (1990). Social Research Methods. $2^{\text {nd }}$ Edition. New York: Prentice Hall.

Durrheim, K. (1999). Quantitative analysis. In M. Terre Blanche and K. Durrheim (Eds.), Research in practice: Applied methods for the social sciences (pp. 96-122). Cape Town: University of Cape Town Press.

Gordhan, P. (2010). Minister of Finance Budget Speech 2010. Pretoria: Price Water House Coopers.

Gouba, L. (2008). The Importance of Mathematics. Muizenbery: African Institute for Mathematical Sciences, South Africa.

Govender, P. (2010). Matric 2009: The sobering aftermath: Sunday Times January 10.

Govender, P. (2010). Minister lays the blame on poor English: Sunday Times; January 10.

Haralambos, M., Holborn, M., and Heald, R. (1995). Sociology: Themes and Perspectives. $4^{\text {th }}$ Edition. London: Harper Collins.

Holsti, R.O.(1969). Content Analysis for the Social Sciences and Humanities. Reading.MA: Addison-Wesley.

Justina, W. G. (1991). Teaching science, technology and mathematics in the mother tongue: Implications for the learners. Stan, 32, 118-122.

Krippendorff, K. (2004). Content Analysis: An Introduction to Its Methodology. $2^{\text {nd }}$ edition. Thousand Oaks. CA: Sage. 
Manuel. A. T. (2008). Budget Speech 2008 by the Minister of Finance, Trevor, A. Manuel 20 February: Last modified: Wednesday 20 February 2008' 16:20:01/SAST.

Manuel, T. A. Minister of Finance Budget Speech. (2009). Pretoria: Formset Printers Cape.

Mbeki, T. (2001). The State of the Nation address of The President of South Africa, Thabo Mbeki, at the National Assembly chamber, Cape Town, 9 February 2001.

Mbeki, T. (2000). Response of The President of South Africa, Thabo Mbeki, to the debate on The State of the Nation Address, National Assembly, Cape Town, 10 February 2000.

McNamara, C. (1998). Basic guide to program evaluation. Retrieved June 28, 2009 from http://www.mapnp.org/library/evaluatn/fnl eval.htm

Motshekga, A. Motshekga at the occasion of the release of the 2008 Matric Results, Parktown Girls High, Johannesburg 2008, Gauteng Province.

Muller, J. (2009). Forms of knowledge and curriculum coherence. Journal of Education and work. 22(3): $205-226$.

Naidoo, D. (2004). Linking the utilizing of research findings to research in MST education. Paper presented at the 21th Annual Conference of the Southern African Association for Research in Mathematics, Sciences and Technology Education: University of Cape Town.

Neuendorf, K. A. (2002).The Content Analysis Guidebook. Thousand Oaks. CA: Sage Publications.

Pandor, N. (2011) Level of maths teaching in South Africa low. 13 July 2011: Sunday World.

Patton, M. Q. (1990). Qualitative Evaluation Research Methods. $2^{\text {nd }}$ Ed. Newbury Park: Sage.

Van der Berg, S. and Burger, R. (2002). Education and Socio-economic differentials: A study of school performance in the Western Cape. Paper to DPRU/FES Conference on Labour Markets and Poverty in South Africa. Johannesburg, 22-24 ${ }^{\text {th }}$ October 2002: University of Stellenbosch.

Van der Berg, S. (2001). Resource shifts in South African schools after the political transition, Development Southern Africa 18(4), October 2001: 309-325.

Weber, R.P. (1990). Basic Content Analysis. 2nd edition. Newbury Park, CA: Sage Publications.

Western Cape Department. (2005). Denaledi project: Creating tomorrow's stars today. Available at http://curriculum.wcape.school.za/site/50/page/view/334

Shapiro, J. (2011). Mail and Guardian 13 January.

Siwela, T. The Citizen February17 2012

Yalo, S. (2011). Sowetan February 22.

Yalo, S. (2011). Sowetan. March 25.

Zuma, G. J. (2009). State of the Nation Address by His Excellency J.G. Zuma, President of the Republic of South Africa, Joint Sitting of Parliament, Cape Town 3 June 2009. 